\title{
Islam and Traditional Titles in Contemporary Lagos Society: A Historical Analysis
}

\author{
Hakeem A. Akitoye \\ Department of Religions and Peace Studies, Lagos State University, Ojo, Nigeria \\ E-mail address: akeemakitoye@yahoo.com
}

\begin{abstract}
Lagos, an area basically inhabited by the Yoruba speaking people of South Western Nigeria and by extension some other parts of West Africa where Islam, Christianity and the African Traditional Religion are still being practised side by side till date with the Africans still being converted to the new faiths without dropping their traditional religion or cultural affiliations. This ideology is very common to the average African who still believes in his culture which has always tainted his way of life or as far as his religion is concerned should not interfere with his culture as the religion as not tacitly condemned some of these practices. This paper intends to examine the extent to which the Yoruba Muslims have been involved in syncretism especially as regards the introduction of the conferment of titles into the Muslim community.
\end{abstract}

Keywords: Lagos; Yoruba Muslims; Islam; Christianity; African Traditional Religion

\section{INTRODUCTION}

Before the introduction of Islam in the African continent, the prevalent religion of the people was the African Traditional religion which unlike the "new" religions had percolated the lives of the indigenous African whose religion was also his culture. Their social was extremely difficult to be separated from their religion, thus it was not quite easy for the new religions to make easy and quick headway in the continent.

This could be seen in the way the two "religions of the book" in the 1890s arrived the area and expanded or in some cases the failure to expand was as result of the way and manner they both entered the continent with Islam coming from across the Trans Saharan trade routes and was widely and in some cases deeply rooted in Western Africa. While Christianity that came by the sea was not quite popular and acceptable by the inhabitants [1].

Although, majority of African are Sunnis or Sufi but the complexity of Islam is revealed in the various schools of thought, traditions and views that constantly content for dominance in many African countries.

It could be inferred that African Islam is not static and is constantly being reshaped by economic and political conditions, African Islam often are adapted to African cultural contents and belief systems forming African orthodoxies as Africans have generally appropriated Islam in a more inclusive manner. 
It must be pointed out at this juncture that African Islam has both local and global dimensions, on the local level it is believed that Muslims operate with considerable autonomy and do not have international organisations that regulate their religious practises this in fact, account for the differences and variations in Islamic practises throughout the continent. African Muslims seem to have preferred to remain moderate and tolerant in the practise of their religion the course Islam has historically followed.

The Yoruba traditional religion is such within which traditional religious beliefs; customs, antiquated social organisation, cults and philosophy are interwoven and since it is the same Yoruba land that embraced Islam there were no reason to doubt the interaction of both Yoruba traditional religion and Islam.

It is within this framework that the Yoruba found themselves where they had a hierarchical political and social system operating in the community where they have an $\mathrm{Oba}$ (King) or head chief and under him are the quarter chiefs while each quarter chief has lesser chiefs who are responsible to the former, there are also Bales (compound heads) who are in charge of individual compounds with Olori Ebi (Head of families) within the compounds. This mode of political and social strata was what Islam met among the Yoruba and since the local politico-socio traditions did not interfere with the tenets of Islam, it became an integral part of it.

It can be concluded that despite the acculturation through the language of Arabic and the Islamic culture anywhere it finds itself and its immediate adaptation to such an environment there are shreds of traditional beliefs in Yoruba land that this so called Muslims have found it difficult to shed thus what is regarded as syncretism among the Yoruba Muslims [2].

Islam a strictly monotheistic religion which states the complete and total submission to the will of God that the Prophet of Islam taught, while also keeping to the guidance of the Holy Qur'an and the Sunnah of the prophet, while modern problems facing Islam and the Muslims are solved by well-informed members of the Muslim community through Ijma translated as consensus of opinion and must be based on the Qur'an [3].

However, traditional religion which is seen to be polytheistic or referred to by Bolaji Idowu as "diffused monotheism" is accentuated by one supreme deity called Olodumare while all other gods are seen to be subordinates to him. Hence, Olodumare is believed to be so far from human beings that there is a need for subordinate deities that acts as intermediaries between them and the supreme deity. Also, within the imagination and experiences of the Yoruba they give titles or names to these deities according to the characters and their effectiveness. This ideology of the Yoruba is that which transcends all aspects of their lives including the political and social life pattern where members of the community are usually conferred with titles according to their activities or contributions in the society.

Lagos was essentially a traditional society where the religion of the indigenous people was the African Traditional religion (ATR) that has been practised by these settlers from time immemorial. This religious picture of Lagos before the advent of Islam being traditional remained largely true until the 1830 s when several factors seemed to have dictated a change while in some cases, it had been the merging of the old practises of all the religions in a harmonious manner and this formed the purpose for this paper.

By the 1930s Islam had not been fully entrenched in the Lagos society but some extraneous factors ensured that this came to pass, for instance, the outbreak of the Jihad led by the great reformer and teacher Sheikh Uthman Dan Fodio in 1804and the establishment of emirates in many parts of modern Nigeria with the movement of Islamic scholars and Clerics down South Western areas known as the forest areas was a direct effect on the appearance of Islam in Yoruba land. 
But by the third decade of the $19^{\text {th }}$ century therefore, Lagos appeared to have had a sizeable population of Muslims made up not only by those that in-coming from the North but also those the repatriated slaves who had settled in the area.

However, it is not clear when Islam actually gained a foothold in the Lagos area but it is certain that it had become noticeable in the royal household of Oba Adele Ajosun and this was as result of the liberal nature of the Oba who was the custodian of the indigenous tradition religion. After the banishment of Oba Adele Ajosun, the Muslim community was put in disarray but the emergence of Kosoko after the death of Oba Oluwole gave the Muslims another opportunity to come together.

The emergence of Oba Akitoye in 1840 as the Eleko appeared to have opened another phase in the history of Islamic development in the Lagos society but the ensuing dispute between Akitoye and Kosoko was to postpone this development as Kosoko had to face an expulsion from Lagos.

His return from exile was to be a rallying point for the scattered Muslims whom he had always supported although he was not known to be a devoted Muslim it would appear that he was tactical enough to know that he needed to appreciate the usefulness of the Muslims in order to further his own political ambition.

Also important to the development of the Muslim community was the activities of the returnee slaves in the second half of the $19^{\text {th }}$ century, who were returning from all parts of the world. The descendants of these returnees were called Creoles while some of them who have become Muslims took on the responsibility of encouraging the indigenous population to embrace Islam.

The activities of the indigenous and returnee slaves in the growth and development of Islam in Lagos forms the thrust of this paper as it is the thinking of this writer that it was as a result of the activities of some prominent and committed Muslims who, at the earlier times contributed immensely to the development of the religion.

This work will attempt to espouse the way and manner these set of individuals were appreciated for their role and how they were compensated or honoured by the Muslim community thus, the reason for the introduction of an institution that awards chieftaincy titles to deserving members of the Lagos Muslim community that is predominantly Yoruba.

\section{CHIEFTAINCY TITLES IN YORUBA LAND (LAGOS $18^{\mathrm{TH}}$ AND $19^{\mathrm{TH}}$ CENTURIES)}

Chieftaincy titles in the Lagos society is that which is basically fashioned after what obtains in Yoruba-land since Lagos is mainly a Yoruba community and as such their cultural and social practices is in consonance with the wider Yoruba community in the South West of Nigeria.

It must be pointed out at this juncture that the traditional Yoruba society has two ways of awarding titles in Yoruba-land. First, titles that are by nature hereditary and which carries political functions within the community and are confined to some families while the other are the honorary titles given to individuals in recognition of their contributions and roles played in the development of the society and this could be bestowed on any deserving member of the society irrespective of which family he/she comes from.

Titles in the Lagos society is that which is fashioned after that which obtains in Yoruba land since Lagos is also inhabited by people of Yoruba extraction and as such their social and cultural practices are that which is in agreement with the Yoruba race. 
In Lagos, the cultural and political set-up of the traditional society includes four distinct classes of Chiefs who are usually members of a particular family that has been prominent in their respective traditional political hierarchy. These groups are four they are: AKARIGBERE whose leader is the ELETU-ODIBO and is still the traditional prime minister of the Oba of Lagos. The next group is the IDEJO or landowners who were sons of the Olofin the first settlers in Lagos and their leader is the OLUMEGBON, the third group is the OGALADE and the leader is OBANIKORO with ASOGBON being the Oba's military commander and he also shares the role of the kingmaker with the ELETU-ODIBO.

Conversely, at the head is the Oba or EKEJI ORISA (companion of the gods) the spiritual essence which he serves makes him a well revered king and he has sole authority over the other arms of government [4].

It must be pointed out here that while some of these titles are hereditary such as that of the Oba of Lagos and the lineage (idile) titles many others are rewards for achievement and the symbols and rituals fit into the Yoruba culture but are manipulated for present day ends [5].

These titles as given by the Oba is usually bestowed on deserving members of the Lagos community who had contributed immensely to the development of the area and as such are being recognised by the community for their role within the community. Such awards are granted to reward achievement within the Lagos Yoruba community this is important for both the grantor and the receiver of the title as this shows that the title is widely recognised.

\section{EVOLUTION OF CHIEFTAINCY TITLES AMONG LAGOS MUSLIMS}

This institution which has been widely acclaimed by the Yoruba world-wide has however been imbibed by the growing Muslim community in Lagos in that it was able to develop its' own chieftaincy institution with the sole aim of awarding titles to deserving members of their community who had played great roles in the growth and development of the Muslim community in Lagos.

Titles among Lagos Muslims began when the title of the Baba Adinni (patron of the religion) was conferred on Pa Runmonkun, a title he held for over fifty years (1841-1891). He was a leading protagonist of the "new" religion and he contributed immensely to the growth and development of Islam in the early days and he was also one of the few who were able to openly criticise the colonial administration for their stand on western education [6].

As the Lagos Muslim expanded more titles were to evolve in order to accommodate the growing number Muslim philanthropists and prosyletisators of the religion. This development eventually percolated other parts of Lagos state like Epe, Ibeju, Mushin, Ikorodu etc.

However, the functions of the title holders in the mosque is more of a social-cultural nature than religious they used to be the ones that arranged for contributions to renovate or rebuild the mosque or buy any necessary materials for use in the mosque, these people are also expected to arrange for social ceremonies like marriages and burials even as far as religious lectures.

But recent history have shown that the role and scope of these titles holders have changed in the Muslim community while the calibre of people that are bestowed with these titles have also changed such that the responsibilities of the title holders have extended in that influential and well-to-do members of the Muslim communities are being incorporated into the management of the mosque.

The title of the Balogun Musulumi is that given to an influential person in the Muslim community and faithful to the Imam as well as the Jam' at (congregation). He is usually a 
wealthy man who may be able to take care of the mosque and community, he wears a dignified dress and in some large cities he rides a horse especially at Id-al-Fitri and Id-al-Kabir festivals. $\mathrm{He}$ is well respected by ruler or Oba (King) and his chiefs [7].

It must be pointed out that the title of the Balogun used to be a title for the Chief Warrior during the inter-tribal wars in Yoruba land and as the War chief who eventually accepted Islam while their followers also converted to the religion. For example the Balogun Kuku in Ijebu Ode, this same title is used for other Muslim communities after the spread of Islam in the area.

The title of the Baba Adinni is at the head of all titleholders in the mosque where he could wield some influence over certain secular issues but not on religious or spiritual issues. Also, the title of the Giwa (Headman) was as a result of the growth and development of Islam in the Island that necessitated the division of the community into wards or sub-districts and from subdistricts evolved the "companies" or "clubs" of young Muslims led by an elderly or middle aged person and such were called "Giwa" or headman.

Other titles that surfaced were the ones given to the lieutenants or those regarded as deputies to the head of the title holders, for example, Durosooto Adinni (the trustworthy), Sonmori Adinni (the elite of the religion), Majeobaje Adinni (the preserver of the religion). Among the womenfolk, there arose associations or groups which concerned itself mainly with religious education and activities and they were known and called the Egbe Alasalatu (prophetic praise singers). This group was a strong religious force among the women; the membership of these groups was initially small compared to the men's' group but it has grown immensely as a result of their activities within the Mosque.

Consisting mainly of Muslim housewives the membership has increased tremendously and as a result of this the title holders within the group also increased as their dedication to the promotion of Islam was not questionable under the leadership of the Iya Sunnah or Olori Alasalatu (head of the Asalatu group).

The history of the title of Iya Adinni (matron of the religion) of the Lagos Muslim community is scanty because this position had not been popular among the Muslims until recently when one Madam Aminatu Omotola Ajose was installed as the first Majeobaje Adinni of Lagos in 1915 [8].

It could be inferred from the above that the evolution of titles among Lagos Muslims was as a result of the need to honour deserving Muslims in the propagation of the religion and to secure their support for the cause of Islam in the future, while also using the award as a way of showing appreciation by the wider Muslim community to the protagonists of the religion.

\section{KEY BENEFICIARIES OF ISLAMIC TITLES IN LAGOS}

Islamic titles have been bestowed on prominent Lagos indigenes and non-indigenes since the late eighteenth century when Muslims within the Lagos society began to recognise the activities of a few of them who had contributed immensely to the development of the Lagos Muslim community as some were being acknowledged by foreign countries already as they were being conferred honorary titles in recognition of their role in the Lagos society.

Among such names was that of Mohammed Shitta a free slave that came into Lagos from Sierra- Leone with 50 of his followers arriving Badagry in 1844 and eventually settled at Martins street on the Island in 1852. The Sultan of Turkey at the opening of the Mohammed Shitta's mosque in July 1894 conferred on him the title "Bey" in recognition of his contribution to Islam in Lagos [9]. 
The title so bestowed upon him by the Sultan of Turkey was the highest distinction that could be bestowed on any civilian and this title simply marked the international recognition for Yoruba Muslims both within and outside Lagos. He was to be awarded the titles of Baba Adinni and Seriki Adinni by the Lagos Muslim community.

Another beneficiary was Ahmad Tijani Awelenje an acknowledge man of learning and a renowned scholar of his time who had travelled far and wide in Yoruba-land propagating the religion of Islam but eventually settling in Lagos in 1920 [10].

At his arrival he set up and organised a Madrasat (Arabic school) at the veranda of his house at Ojogiwa Street in Lagos where as a result of his proficiency and dedication to the cause of teaching Muslim children Arabic he was popularly called "Alfa Shaki" as a result of the fact that he relocated from Shaki to Lagos.

He contributed immensely to Islamic learning in the Lagos area while also making the teaching of Arabic language a worthwhile venture. He went as far as Masjid-al-jami, the Central mosque of Sudan between 1939 and 1941 [11] when he was on pilgrimage to the holy cities of Makah and Medina where he was able to gather some books for his Madrasat.

Ahmed Tijani Awelenjes' objective was to consolidate the religion of Islam's' position in Lagos and to encourage the hitherto secretive Muslims to be bold enough to come and practise their religion. As a result of this he became the arrowhead of the Yoruba Muslims in particular and Nigeria in general.

He was behind the establishment of the United Muslim Council and also in 1958 in conjunction with the Late Obafemi Awolowo he fought for and achieved the establishment of the Muslim Pilgrims Welfare Board of the then Western Nigeria [12].

As a result of the contributions of Ahmad Tijani Awelenje to the growth of Islam in Yoruba-land and was also turbaned the Aare Musulumi of Yoruba-land on the $13^{\text {th }}$ of November, 1961 and was also bestowed with the prestigious award of the Member of the British Empire (MBE) in September 1962.

Another illustrious Muslim who was awarded title for his role in the development of Islam in Lagos was Jubril Martins who was born in November, 1888 in Popo Aguda (Brazilian quarters) of Lagos Island to a prominent Muslim family of Harun Jose Martin but contrary to widely held view the family is not of Brazilian origin but the is said to have originated from the Arabic word "Al-Matin" (The firm one) one of the ninety-nine names of Allah [13].

Jubril Martin had his primary and secondary education at St. Francis (holy Cross Cathedral) and the prestigious St. Gregory's' College respectively; on the completion of his high school education he joined the Colonial civil service in 1907 and rose steadily to the status of first clerk [14] a rare privilege in those days.

His first mark on Islam took place in 1916 when he joined with some Muslims to establish the Ahmadiyyah movement in Islam becoming the general Secretary in 1919 with L. B. Agusto as the vice president. In 1923 he resigned his appointment with the Colonial government and proceeded to the University College, London where he obtained his LLB degree in Law in 1926 becoming the first Muslim Lawyer to be called to the outer Bar of Lincoln Inn in 1926 [15].

On his arrival in Nigeria, acutely aware that the Nigerian Muslims were educationally disadvantaged vis-à-vis their Christian counterparts, Jubril Martin on his assumption of the Presidency of the Ahmadiyyah movement established the education committee consisting of Alhaji Issa Williams as Chairman as a practical demonstration of his interest in Muslim education.

As a practical demonstration of this interest in Muslim education his group the Ahmadiyyah Movement in Islam established the first Muslim voluntary agency school which 
was built at 4-6 Olushi Street in Lagos and the property was owned by him while he also had to sell off some his properties in order to meet the travel expenses of many Muslims students to the Middle-East where they had been offered scholarships [16].

Jubril Martin was a great promoter of the Muslim cause and perhaps the most outstanding spokesman in the 1940s' and 50s'. He also championed the campaign that the Nigerian government should take care of its' citizens on pilgrimage to Makah and Medina, thus the establishment of the Nigerian Pilgrims Welfare Board.

\section{CONCLUSIONS}

Conferment of Islamic titles in the Lagos Muslim community was an idea copied from the traditional Yoruba Society where prominent members of the society are conferred with honorary titles in recognition of the roles played by those individuals in the growth and development of the society.

This institution has since come a long way in that it has become a part of the Muslim socio-cultural establishment as many Muslim are still being recognised by the Muslim groups, association and community at large till today. In essence, the practice of awarding to individuals by the Muslim community as constituted by the Lagos Muslim community has been able to bring into the Muslim community a sense of belonging among the Muslims especially the well to do and this has become a tool for the promotion of the religion in Lagos society till date. In the writers opinion generally speaking Lagos Muslims like any other African societies belong to a closely knitted group within which every individual shares its' happiness and miseries in common and also resist any attempt to disrupt the social, cultural and political settings of the community.

The Islamic culture has been able to keep this attitude of Muslims or Yoruba within the social strata of the Community while it also resists also the destructive influences of the disintegration of families and kinship coming from other societies to influence it. Thus, it was easy for the Yoruba Muslims to institute and integrate a reward system that appreciate the members of the community and this culminated in the establishment of the Islamic chieftaincy institution designed to reward excellence.

\section{References}

[1] Isichei Elizabeth, History of West Africa since 1800. Africana publishing company, New York, 1977, p. 12.

[2] Doi Abdurrahman, Islam in Nigeria. Ghaskiyah Corporation, Zaria. 1984, p. 236.

[3] Doi Abdurrahman, Ibid. p. 237.

[4] Eades J. I., The YorubaToday. Cambridge University Press, London. 1980. p. 180.

[5] Ibid. p. 95.

[6] Thanni Raheem,"Alhaji Azeez Ajagbemokeferi and his da'wah activities". An unpublished B.A project submitted to the Department of Arabic and Islamic studies, University of Ibadan, 1986, p. 72.

[7] Doi Abdurrahman. p. 202. 
[8] Adekunle Alli, Brief on Olori Giwa-Giwa title published in the Lagos News, $18^{\text {th }}$ Feb. 1989 , p. 3.

[9] Oyeweso 'Siyan, Eminent Yoruba Muslims. Rex Charles publications, Ibadan. 1999, p. 3.

[10] Akitoye Hakeem," Islam and chieftaincy titles in Lagos Island since 1775" an unpublished thesis submitted to the department of Religions, Lagos State University, and Ojo, 2002. p. 52.

[11] Akitoye Hakeem, Ibid. p. 52.

[12] Akitoye Hakeem, Ibid. p. 53.

[13] Oyeweso 'Siyan, op Cit. p. 126.

[14] Ibid.

[15] Fafunwa B. A., Up and On: A Nigerian Teachers Odyssey. West African Book Publishers, Lagos. 1990, p. 186.

[16] Oyeweso 'Siyan, op, p. 128. 